Journal of Engineering and Applied Sciences 14 (Special Issue 9): 10723-10732, 2019

ISSN: 1816-949X

(C) Medwell Journals, 2019

\title{
Preparation and Characterization of Mg/Fe-LDH Nano Hybrids with (O, O-Diethyl O-3, 5, 6-Trichloro-2-Pyridyl Phosphorothioate (Chlorpyrifos) by Direct and Indirect Ion Exchange Method
}

\author{
Eussur Al-Khafaji, Maryam Mansoor Mathkoor and Alaa A. Ali \\ College of Pharmacy, University of Ahle AL-Bait, Karbala, Iraq
}

\begin{abstract}
The study present the synthesis nano compound through a process intercalation of insecticide (chlorpyrifos) in $\mathrm{Mg} / \mathrm{Fe}-\mathrm{LDHs}$ by indirect ion exchange. Characterization of this compound (chlorpyrifos, $\mathrm{Mg} / \mathrm{Fe}-\mathrm{LDHs}$ and nano compound) done by DXR technique and FT-IR spectrophotometer before and after intercalation formation of nano compound, then cooperation to sure the form nano hybrid organic-inorganic compound and the two and three dimensional image of the above compound in Atomic Force Microscope (AFM) for the layer and nano compound. The aim of this study, is the synthesis hybridnano compounds can be controlled release insecticide (Chlorpyrifos) by ion exchange process for limited of environment pollution. The results appeared the release of hybrids to specific liquids in different $\left(\mathrm{Na}_{2} \mathrm{CO}_{3}, \mathrm{Na}_{2} \mathrm{PO}_{4}\right)$ concentration $(0.5 \mathrm{~m})$ by direct and indirect ion exchange method. It was found to be contorted by parabolic diffusion at the opening of the process then again the whole process is governed by pseudo-second order rate appearance according to Lagregrans equation addition the studied percentage of rate release for both anionic (Chlorpyrifos) from $\mathrm{Mg} / \mathrm{Fe}-\mathrm{LDHs}$ The results high percentage of release in different liquid follows this arrangement: $\mathrm{Na}_{2} \mathrm{CO}_{3}>\mathrm{Na}_{2} \mathrm{PO}_{4}$.
\end{abstract}

Key words: Image, insecticide, compound, cooperation, FT-IR

\section{INTRODUCTION}

Insecticides can be biological activity molecules that have extrusive use in agriculture, leading to direct contact by uses it is also possible that these particles seep into soil and groundwater one of the problems experienced by this sector it also has effects on human health which affects the human nervous system as well as the growth and immunity of children adding to the risk of causing lung cancer in order to reduce the phenomenon of pollution by these materials it is possible to use a method to control release of these molecules in the form of ions and applying the technique of nanoparticles, represented by the (LDHs) are a group of compounds carry positively charged layers with anions and water molecules intercalated in the interlayer and often called anionic clay comparing with the more conservative cationic clay is the most commonly investigated anionic clay and is rarely found in nature (Cavani et al., 1991). The chemical composition of LDHs is represented by general formula (Vaccari, 1998; Khan and O'Hare, 2002; Rives, 2001; Evansa and Duan, 2006) $\left[\mathrm{M}^{2+}{ }_{1-\mathrm{x}} \mathrm{M}^{3+}{ }_{\mathrm{x}}(\mathrm{OH})_{2}{ }^{\mathrm{x}}\right]\left[\mathrm{An}^{-} \mathrm{x}\right.$ - $-\mathrm{s}$ $\mathrm{YH}_{2} \mathrm{O}^{\mathrm{x}-}$ divalent cation such as $\mathrm{M}^{2+}=\mathrm{Mg}^{2+}, \mathrm{Zn}^{2+}, \mathrm{Co}^{2+}$, $\mathrm{Ni}^{2+}, \mathrm{Mn}^{2+}$ is a trivalent cation such as $\mathrm{M}^{3+}=\mathrm{Al}^{3+}, \mathrm{Fe}^{3+}$, $\mathrm{Cr}^{3+}, \mathrm{Ga}^{3+}, \mathrm{V}^{3+}$. The $\mathrm{M}^{\mathrm{II}} / \mathrm{M}^{\mathrm{III}}$ molar ratio usually lies between ( 2 and 5$)$. The layers as a result, take a positive charge (Ookubo et al., 1993). This value is attributed to the charge density of the hydroxide basal layer, namely, Anion Exchange Capacity (AEC). LDHs layer have a positive charge diffusion on the surface of them due to the $\mathrm{M}^{+3}$ substituted for the $\mathrm{M}^{+2}$ and the interlayer space is neutralized by the intercalation of anions with water molecules. The intercalation of various anions into LDHs has been classify by the following methods: calcination-rehydration (reconstruction), ion exchange, co-precipitation, thermal reaction and hydrothermal reactions (Aisawa et al., 2001), $\left(\mathrm{A}^{\mathrm{n}-}\right)$ is an ion exchangeable anion such as $\mathrm{OH}^{-}, \mathrm{Cl}^{-}, \mathrm{NO}^{3-}, \mathrm{CO}_{3}{ }^{2-}$, $\mathrm{SO}_{4}{ }^{2-}$ and various organic anions (Arizaga et al., 2009; Raki et al., 1995; Whilton et al., 1997) but also organic anions, complex anions, herbicides, insecticides (Franklin et al., 1995; Carlino, 1977), pharmaceuticals (Ookubo et al., 1993).

These layers (Mg/Fe-LDHs) have the capability to capture active molecular such as phosphorus organic insecticide (chlorpyrfose) in the form anion bonded between the layer to form nano crystalline hybrid organic inorganic where the layer represent the host part but the packed anion represent the guest as shown in Fig. 1. 


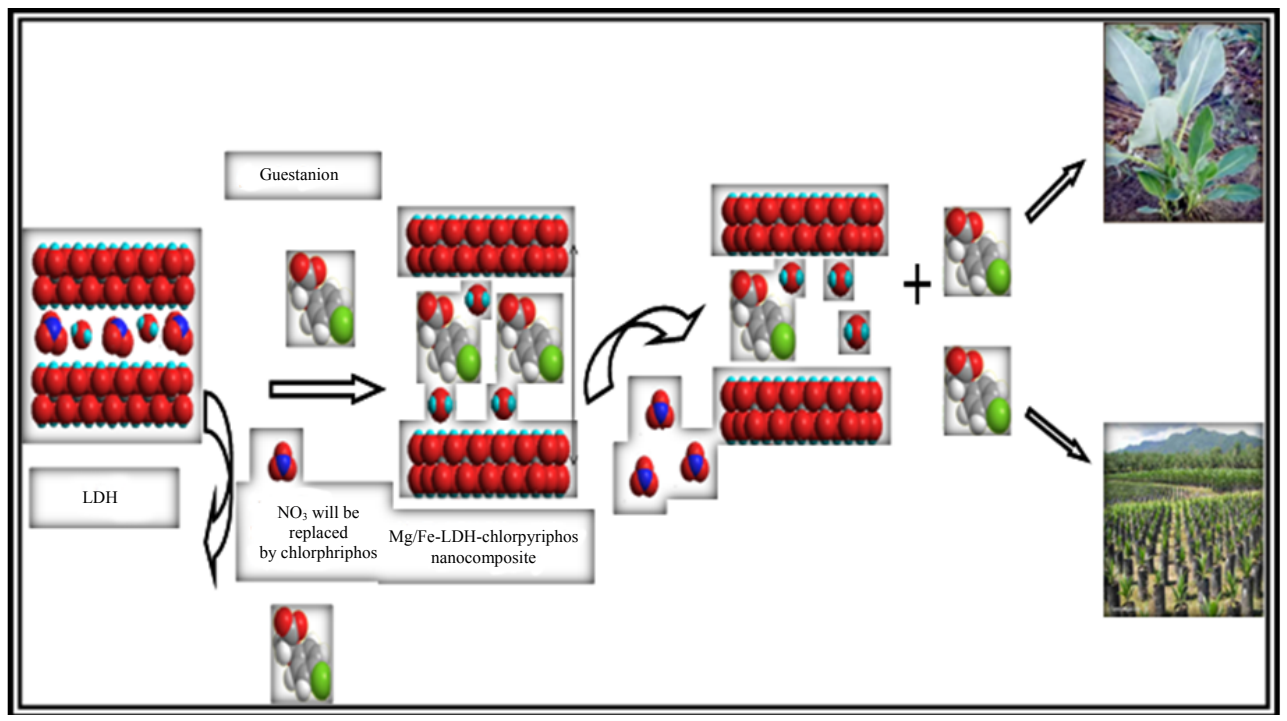

Fig. 1: Demonstrates the intercalation anion (chlorpyrofose) in $\mathrm{Mg} / \mathrm{Fe}-\mathrm{LDHs}$

\section{MATERIALS AND METHODS}

Experimental part: *Synthesis of $\mathrm{Mg} / \mathrm{Fe}-\mathrm{LDH}$ by co-precipitation method. The natural $\mathrm{NO}_{3}-\mathrm{LDHs}$ were prepared by a standard Co-precipitation method. A mixed dissolved weight of $(2.5 \mathrm{~g})$ of $\left(\mathrm{Mg}\left(\mathrm{NO}_{3}\right)_{2} \cdot 6 \mathrm{H}_{2} \mathrm{O}\right)$ and $(2.01 \mathrm{~g})$ of $\left(\mathrm{Fe}\left(\mathrm{NO}_{3}\right)_{3} 9 \mathrm{H}_{2} \mathrm{O}\right)$ when $\left.\mathrm{R}=2\right)$ in $100 \mathrm{~mL}$ ethanol, solution at $44^{\circ} \mathrm{C}$ with stirring and the postponement for $18 \mathrm{~h}$. The solution $\mathrm{pH}$ was adjusted at (Raki et al., 1995) for th $\mathrm{eMg} / \mathrm{Fe}-\mathrm{LDHs}$ by drop wise addition of $(2 \mathrm{M}) \mathrm{NaOH}$ solution during the instillation of the mixed solution separate the precipitate the washing by DW and drying at $40^{\circ}$.

*The nano compound prepare by two methods First method (indirect ion exchange): Dissolved $(2.5 \mathrm{~g})$ of $\mathrm{Mg}\left(\mathrm{NO}_{3}\right)_{2} \quad 6 \mathrm{H}_{2} \mathrm{O}(2.01 \mathrm{gm}) \mathrm{Fe}\left(\mathrm{NO}_{3}\right) 9 \mathrm{H}_{2} \mathrm{O}$ in $100 \mathrm{~mL}$ ethanol when molar Ratio $(\mathrm{R}=2)$, adjusted the $\mathrm{pH}$ at (10) by (2M) sodium hydroxide, gradually addition $500 \mathrm{ppm}$ of (chlorpyrifose) dissolved in $100 \mathrm{~mL}$ ethanol incubate the solution in water bath with shaking at $44^{\circ} \mathrm{C}$ for $18 \mathrm{~h}$, separate the precipitate the washing by DW and drying at $40^{\circ}$.

Second method (direct ion exchange): Dissolve $(0.4 \mathrm{~g})$ of $\mathrm{Mg} / \mathrm{Fe}-\mathrm{LDH}$ which prepare by Co-precipitation method. In $100 \mathrm{~mL}$ ethanol, gradually addition $1000 \mathrm{ppm}$ of (chlorpyrifose) dissolved in $100 \mathrm{~mL}$ ethanol, adjusted the $\mathrm{pH}$ at (5.5) by (2M) sodium hydroxide. Incubate the solution in water bath with shaking at $44^{\circ} \mathrm{C}$ for $18 \mathrm{~h}$, separate the precipitate the washing by DW and drying at $40^{\circ}$.

*Kinetic controlled release of (ascorbic acid): Using dirct ion exchange to release (chloropyrifose) from host
$(\mathrm{Mg} / \mathrm{Fe}-\mathrm{LDH})$ to dilute solution $(0.5 \mathrm{M})$ from $\mathrm{Na}_{2} \mathrm{SO}_{4}$, $\mathrm{Na}_{2} \mathrm{PO}_{4}$ then measure the release concentration of anion ion by U.V ray at the $\lambda_{\max }=260 \mathrm{~nm}$.

*Study of percentage to release (chlorpyrifose) from nano hybrid compound: Using UV ray to study percentage to releaseanion by taking solution $(0.001 \mathrm{~g})$ nano compound dissolve in $3.5 \mathrm{~mL}$ from $\mathrm{HCl}(2 \mathrm{M})$ then measure the absorbance at $\lambda_{\max }$ to determine the total concentration of anion in layer $\mathrm{C}_{\mathrm{T}}$ as the following equation.

\section{RESULTS AND DISCUSSION}

Figure 2 explains of X-ray diffraction through the different in the value of thin layer before and after intercalation the inion ion inter the layer by using the Bragg low (Bragg, 1993) $(2 \mathrm{~d} \sin \theta=\mathrm{n} \lambda)$ while $(\lambda=$ $\left.1.540562 \mathrm{~A}^{0}\right), \mathrm{n}=1$ is the different in value of the thin layer causes by the affect of volume and the chemical structure for the organic molecular in the layer double hydroxide and figure show the crystal level is (hkl) from (003), (006) and (009), the before the intercalation $d=$ $8.8 \mathrm{~A}^{0}$ of $(003)$ is angle $\left(5^{0}\right), \mathrm{d}=4.4 \mathrm{~A}^{0}$ of $(006)$ is angle $\left(10^{\circ}\right)$ and $\mathrm{d}=2.9 \mathrm{~A}^{0}$ but after the intercalation of (chloropyrophose) $\mathrm{d}=29.5 \mathrm{~A}^{0}$ at the same of the crystal level the angle is deflection $\left(1.5^{\circ}\right), \mathrm{d}=7.3$ of $(006)$ is angle $\left(6^{0}\right)$ and $d=4.9 A^{0}$ of $(009)$ is angle $\left(9^{0}\right)$ this result show the succeed intercalation of (chloropyrophose) between $\mathrm{Mg} / \mathrm{Fe}$ LDHs. Figure 3-5, explains was characterized by using Atomic Force Microscope (AFM) for the two and three-dimensional image to layer $\left(\mathrm{Mg} / \mathrm{Fe} \mathrm{NO}_{3}-\mathrm{LDH}\right)$ and hybrid nano compounds recorded in direct indirect ion exchange method ( $\mathrm{Mg} / \mathrm{Fe}$-chloropyrifose-LDH). 


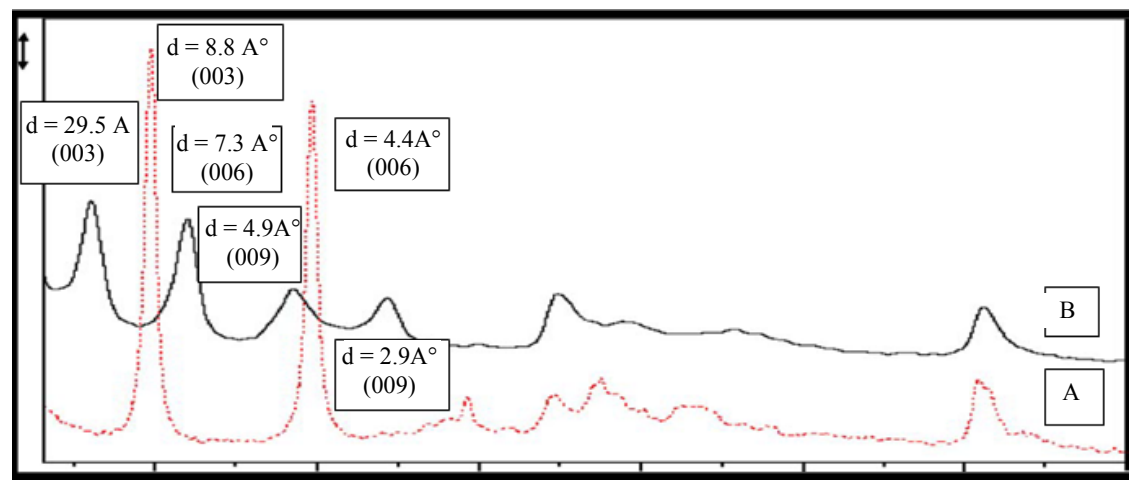

Fig. 2: Powder DXR patterns for (A) $\mathrm{Mg} / \mathrm{Fe} \mathrm{NO}_{3}$-LDH and (B) $\mathrm{Mg} / \mathrm{Fe}$-chlorpyrifose-LDH
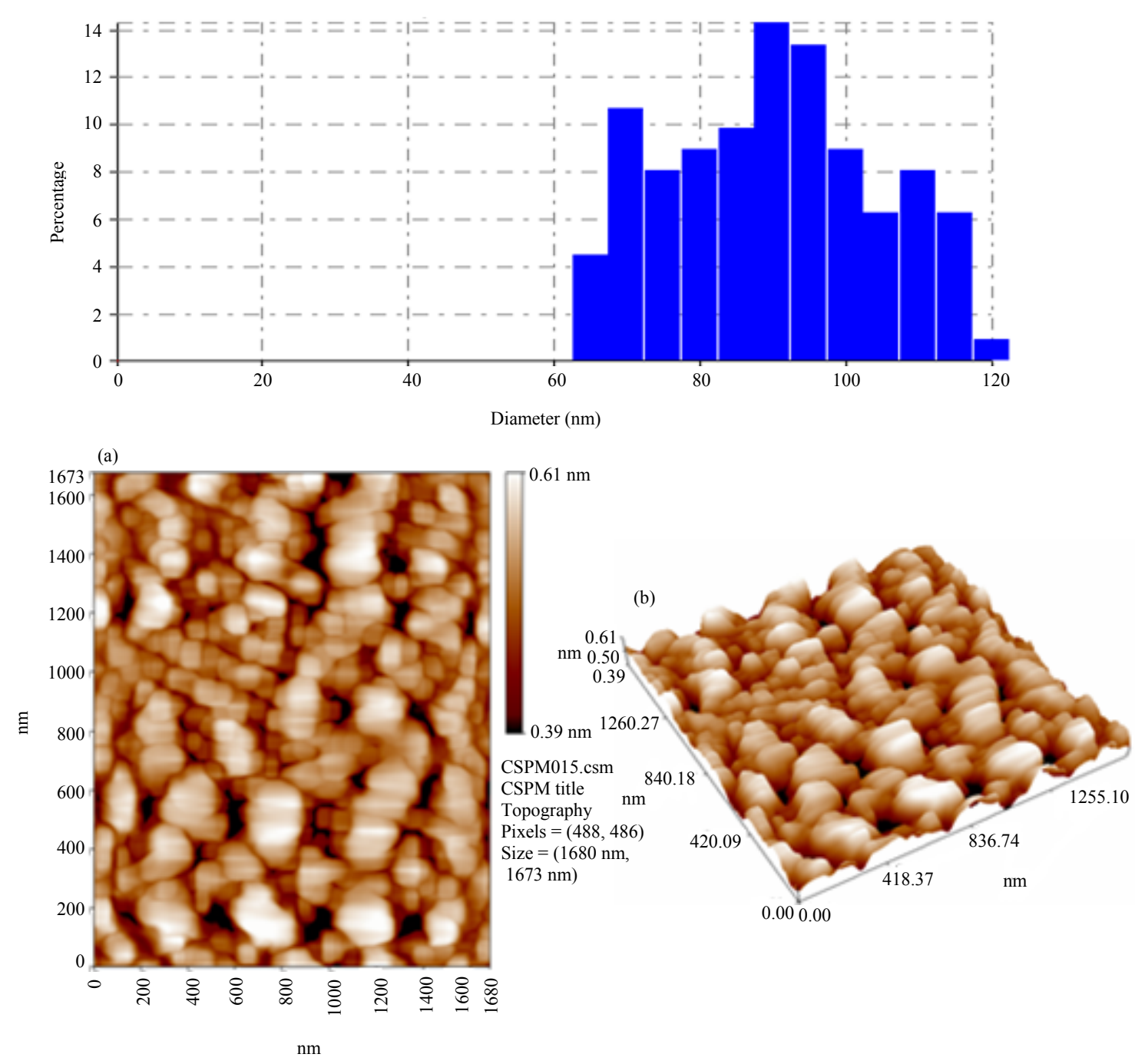

Fig. 3(a, b): AFM image of (Mg/Fe-LDH), (a) Two-dimensional image and (b) Three-dimensional image

Figure 3a the image shows two-dimensional layer before intercalation process where molcular clusters appear while Fig. $3 \mathrm{~b}$ were show the three-dimensional image high molecular assemblies which has limitsrange 
Table 1: The diameters, sizes and aggregation of the molecular in $\left(\mathrm{Mg} / \mathrm{Fe} \mathrm{NO} \mathrm{NO}_{3}-\mathrm{LDH}\right)$

\begin{tabular}{|c|c|c|c|c|c|c|c|c|}
\hline \multicolumn{9}{|c|}{ Avg. Diameter: $87.50 \mathrm{~nm}$} \\
\hline $\begin{array}{l}\text { Diameter } \\
(\mathrm{nm})<\end{array}$ & $\begin{array}{c}\text { Volume } \\
(\%)\end{array}$ & $\begin{array}{c}\text { Cumulation } \\
(\%)\end{array}$ & $\begin{array}{c}\text { Diameter } \\
(\mathrm{nm})<\end{array}$ & $\begin{array}{c}\text { Volume } \\
(\%)\end{array}$ & $\begin{array}{c}\text { Cumulation } \\
(\%)\end{array}$ & $\begin{array}{c}\text { Diameter } \\
(\mathrm{nm})<\end{array}$ & $\begin{array}{c}\begin{array}{c}\text { Volume } \\
(\%)\end{array} \\
\end{array}$ & $\begin{array}{c}\text { Cumulation } \\
(\%)\end{array}$ \\
\hline 65.00 & 4.46 & 4.460 & 85.00 & 9.82 & 41.96 & 105.00 & 6.25 & 84.82 \\
\hline 70.00 & 10.71 & 15.180 & 90.00 & 14.29 & 56.25 & 110.00 & 8.04 & 92.86 \\
\hline 75.00 & 8.04 & 23.210 & 95.00 & 13.39 & 69.64 & 115.00 & 6.25 & 99.11 \\
\hline 80.00 & 8.93 & 32.140 & 100.00 & 8.93 & 78.57 & 120.00 & 0.89 & 100.00 \\
\hline
\end{tabular}
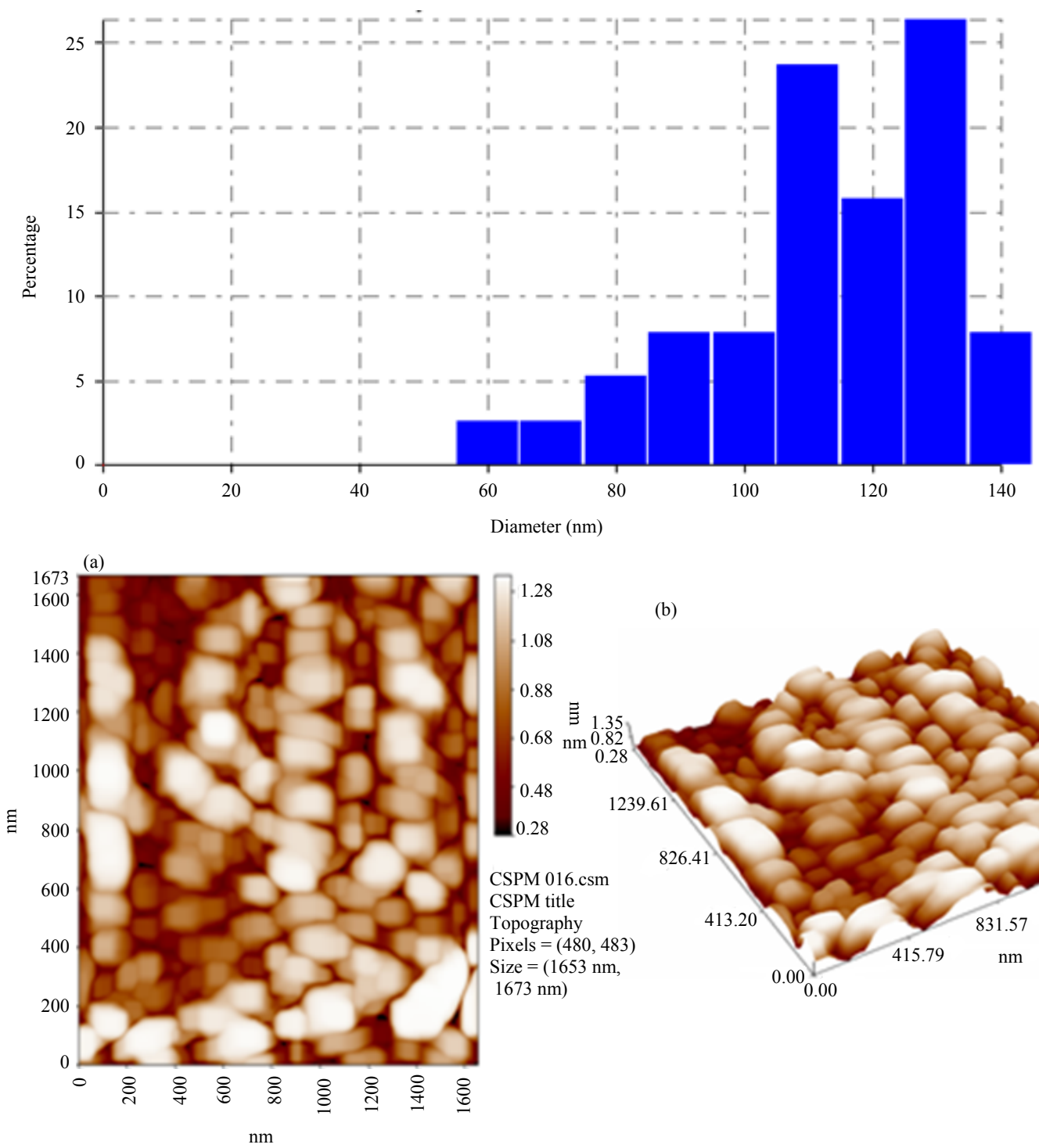

(b)

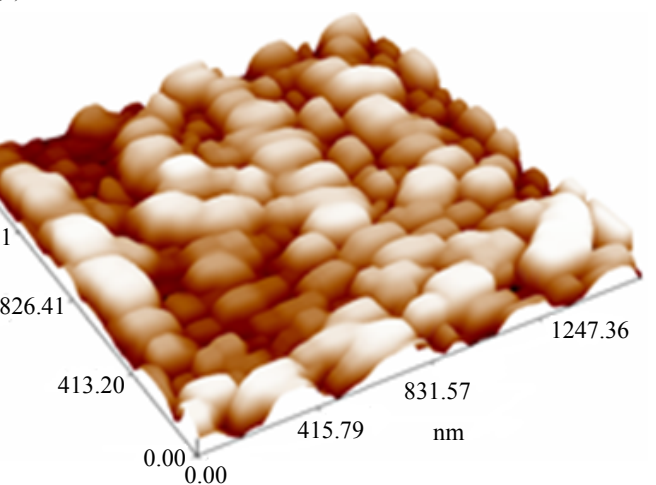

Fig. 4(a, b): AFM image of ( $\mathrm{Mg} / \mathrm{Fe}-($ cloropyrophose)-LDH) prepared by indirect ion exchange method, (a) Two-dimensional image and (b) Three-dimensional image

$(0.39-0.61 \mathrm{~nm})$, shows the diameters sizes and aggregation of the molecular in layer $(\mathrm{Mg} / \mathrm{Fe} \mathrm{NO}-\mathrm{LDH})$ the means of particle size $(87.5 \mathrm{~nm})$ Table 1 before the intercalation process anion.

Figure $4 \mathrm{a}$ the image shows two-dimensional of nano compound prepared by indirect ion exchange method showing molecular clusters of spherical shapes while Fig. $3 \mathrm{~b}$ were show the three-dimensional image for section of the surface of the nano compound $\mathrm{Mg} / \mathrm{Fe}$-chlorpyrifose-LDH showing the high of the molecular clusters that are within limits (0.28-1.28), suggesting (Shaheed et al., 2014) the manufacture of nano 
Table 2: The shows the diameters, sizes and aggregation of the molecular in ( $\mathrm{Mg} / \mathrm{Fe}$ (cloropyrifose - $\mathrm{LDH})$ prepared by indirect ion exchange method

\begin{tabular}{|c|c|c|c|c|c|c|c|c|}
\hline \multicolumn{9}{|c|}{ Avg. Diameter:108.08 nm } \\
\hline $\begin{array}{l}\text { Diameter } \\
(\mathrm{nm})<\end{array}$ & $\begin{array}{c}\text { Volume } \\
(\%)\end{array}$ & $\begin{array}{c}\text { Cumulation } \\
(\%)\end{array}$ & $\begin{array}{l}\text { Diameter } \\
(\mathrm{nm})<\end{array}$ & $\begin{array}{c}\text { Volume } \\
(\%)\end{array}$ & $\begin{array}{c}\text { Cumulation } \\
(\%)\end{array}$ & $\begin{array}{c}\text { Diameter } \\
(\mathrm{nm})<\end{array}$ & $\begin{array}{c}\text { Volume } \\
(\%)\end{array}$ & $\begin{array}{c}\text { Cumulation } \\
(\%)\end{array}$ \\
\hline 60.00 & 2.63 & 2.63 & 90.00 & 7.89 & 18.42 & 120.00 & 15.79 & 65.79 \\
\hline 70.00 & 2.63 & 5.26 & 100.00 & 7.89 & 26.32 & 130.00 & 26.32 & 92.11 \\
\hline 80.00 & 5.26 & 10.53 & 110.00 & 23.68 & 50.00 & 140.00 & 7.89 & 100.00 \\
\hline
\end{tabular}
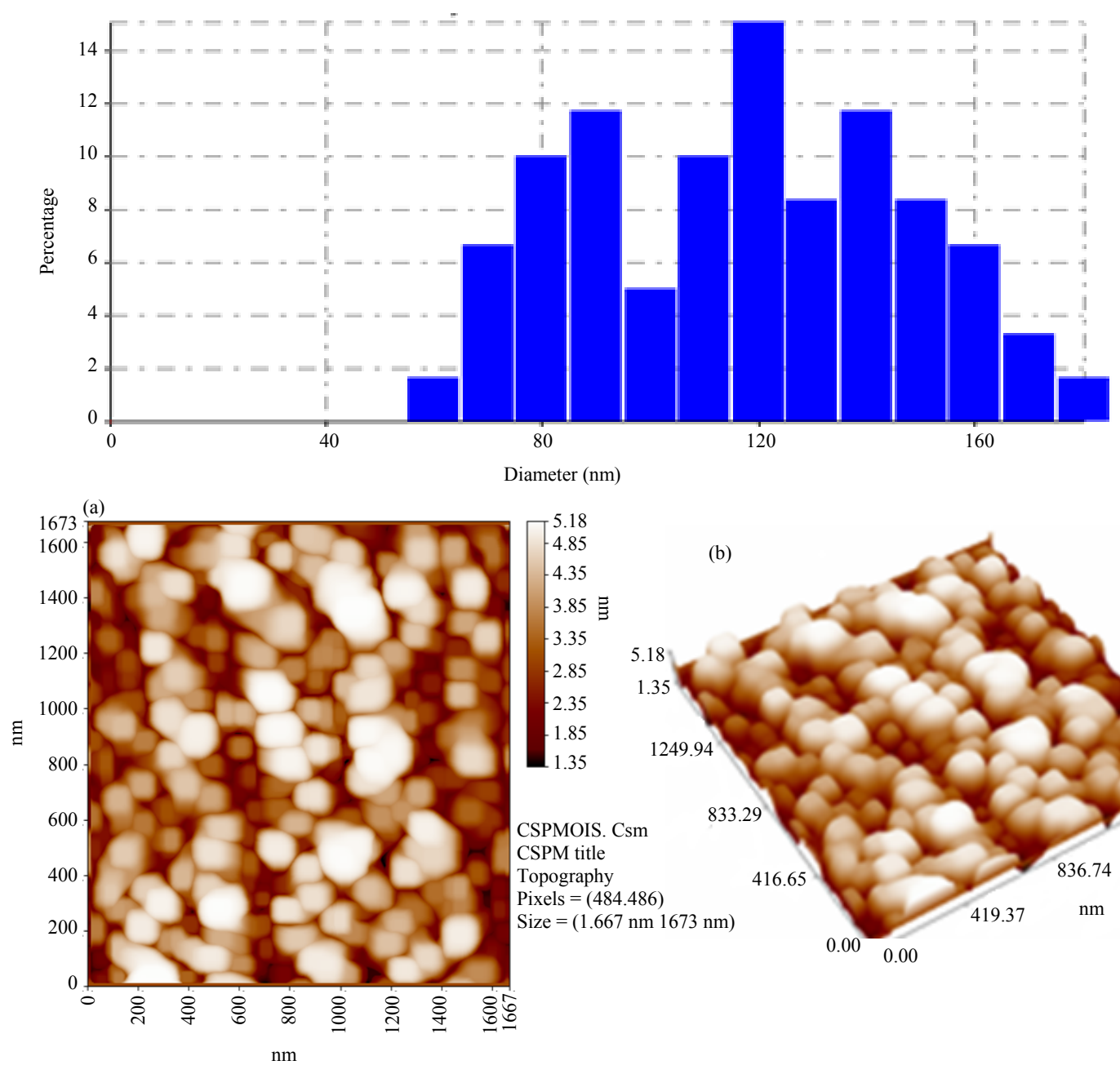

(b)
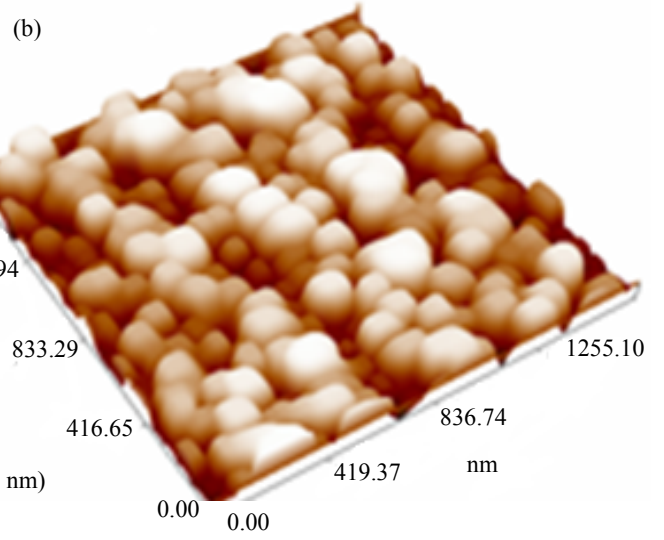

Fig. 5(a, b): AFM image of (Mg/Fe(cloropyrifose)-LDH) prepared by direct ion exchange method, (a) Two-dimensional image (b) Three-dimensional image

compound from insecticide (chloropyrifose) and layer $(\mathrm{Mg} / \mathrm{Fe}-\mathrm{DH})$ as shown in Table 2 means of particle size of nano compound (108.08 nm).

Figure 5a the image shows two-dimensional of nano compound prepared by direct ion exchange method showing molecular clusters of spherical shapes while Fig. $3 b$ were show the three-dimensional image for section of the surface of the nano compound $\mathrm{Mg} / \mathrm{Fe}$-chloropyrifose-LDH showing the high of the molecular clusters that are within limits (1.35-5.18), suggesting (Shaheed et al., 2014) the manufacture of nano compound from insecticide (chloropyrifose) and layer $(\mathrm{Mg} / \mathrm{Fe}-\mathrm{DH})$ as shown in Table 3 means of particle size of nano compound (112.05 nm).

Figure 6-8 explains FT-IR spectrum of insecticide (chloropyrophose) layer (Mg/Fe-LDH and (Ni/Alchloropyrifose-LDH).

The chloropyrophose shows the assimilation peaks of Aliphatic vC-H stretch in the $\left(2966 \mathrm{~cm}^{-1}\right)$, the absorption peaks of Aromatic vC-H stretch in the $3059 \mathrm{~cm}^{-1}$ at $844 \mathrm{~cm}^{-1}$ of absorption peaks of $\delta_{\mathrm{C}-\mathrm{H}}$ aromatic, absorption peaks of acidic vC-O stretch at $1163 \mathrm{~cm}^{-1}$, absorption 
Table 3: The diameters, sizes and aggregation of the molecular in ( $\mathrm{Mg} / \mathrm{Fe}$ (cloropyrifose- $\mathrm{LDH})$ prepared by direct ion exchange method

\begin{tabular}{|c|c|c|c|c|c|c|c|c|}
\hline \multicolumn{9}{|c|}{ Avg. Diameter: $112.05 \mathrm{~nm}$} \\
\hline $\begin{array}{l}\text { Diameter } \\
(\mathrm{nm})<\end{array}$ & $\begin{array}{c}\text { Volume } \\
(\%)\end{array}$ & $\begin{array}{c}\text { Cumulation } \\
(\%)\end{array}$ & $\begin{array}{c}\text { Diameter } \\
(\mathrm{nm})<\end{array}$ & $\begin{array}{c}\text { Volume } \\
(\%)\end{array}$ & $\begin{array}{c}\text { Cumulation } \\
(\%)\end{array}$ & $\begin{array}{l}\text { Diameter } \\
(\mathrm{nm})<\end{array}$ & $\begin{array}{c}\text { Volume } \\
(\%)\end{array}$ & $\begin{array}{c}\text { Cumulation } \\
(\%)\end{array}$ \\
\hline 60.00 & 1.67 & 1.67 & 110.00 & 10.00 & 45.00 & 160.00 & 6.67 & 95.00 \\
\hline 70.00 & 6.67 & 8.33 & 120.00 & 15.00 & 60.00 & 170.00 & 3.33 & 98.33 \\
\hline 80.00 & 10.00 & 18.33 & 130.00 & 8.33 & 68.33 & 180.00 & 1.67 & 100.00 \\
\hline 90.00 & 11.67 & 30.00 & 140.00 & 11.67 & 80.00 & & & \\
\hline 100.00 & 5.00 & 35.00 & 150.00 & 8.33 & 88.33 & & & \\
\hline
\end{tabular}

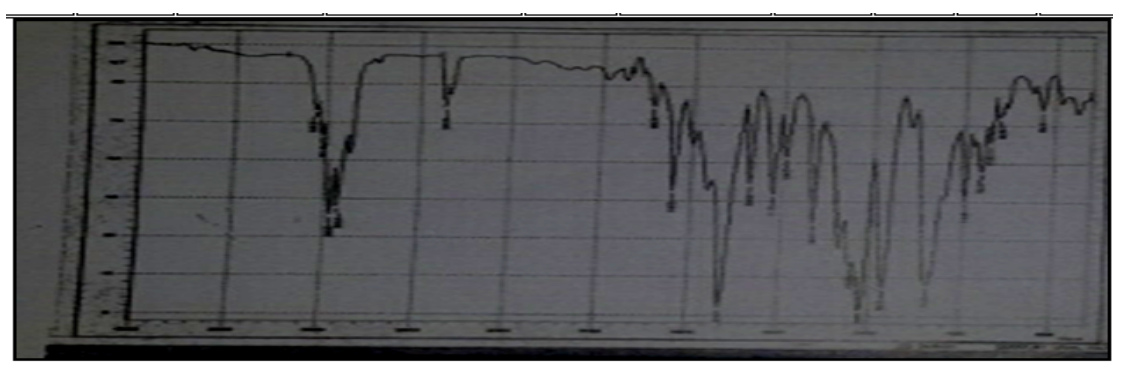

Fig. 6: FT-IR spectrum of chlorpyrifose

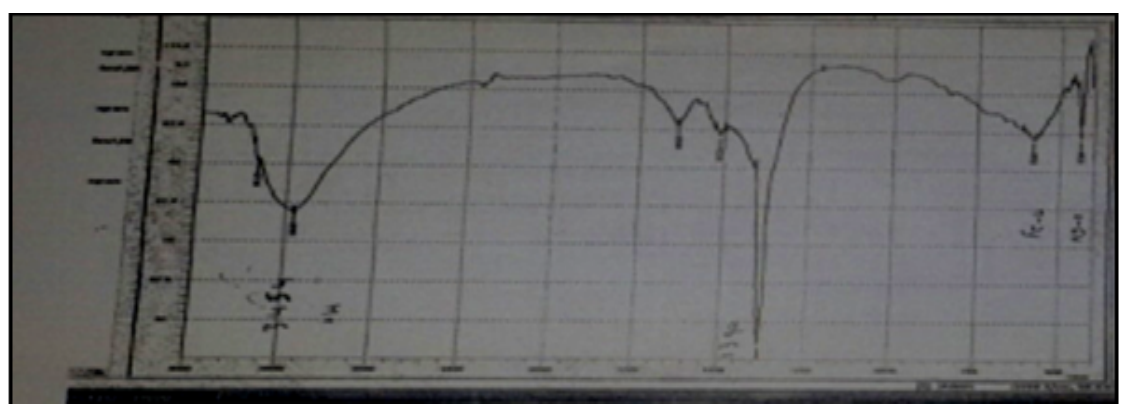

Fig. 7: FT-IR spectrum of $\left(\mathrm{Mg} / \mathrm{Fe}-\mathrm{NO}_{3}-\mathrm{LDH}\right)$

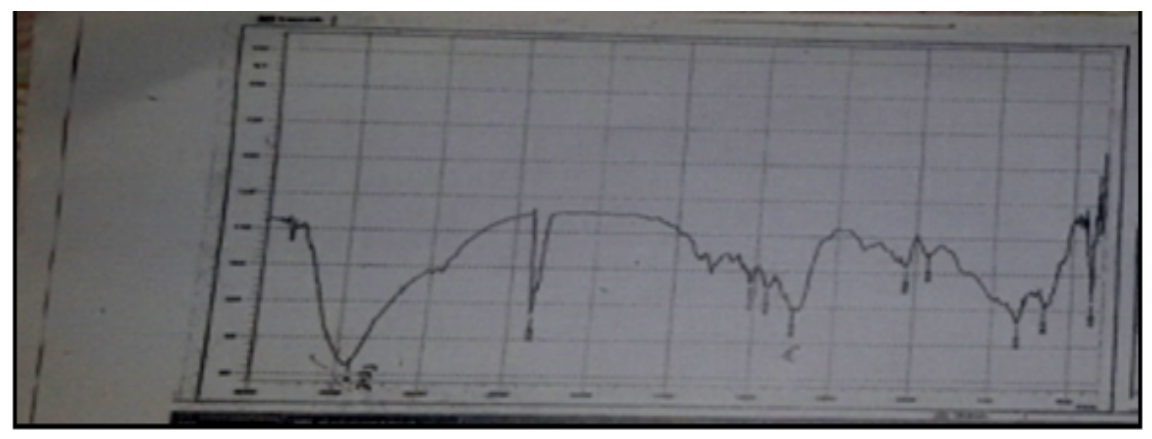

Fig. 8: FT-IR spectrum of nano hybrid compound

peaks of $(v C=C)$ aromatic in the $\left(1477-1589 \mathrm{~cm}^{-1}\right)$ region, absorption two peaks of $v(\mathrm{P}-\mathrm{O}-\mathrm{alkyl})$ and (P-O-aryl) at $\left(1024 \mathrm{~cm}^{-1}\right)$ and $\left(1240 \mathrm{~cm}^{-1}\right)$. (18) at assimilation $\mathrm{N}=\mathrm{C}$ apper $\left(1606 \mathrm{~cm}^{-1}\right)$ but peak at the $\left(966 \mathrm{~cm}^{-1}\right)$ it is Cl-aryl Table 4 and Fig. 6.

The layers, $\left(\mathrm{Mg} / \mathrm{Fe}-\mathrm{NO}_{3}-\mathrm{LDH}\right)$ show the absorption peaks to $v \mathrm{O}-\mathrm{H}$ group stretches at $\left(3454 \mathrm{~cm}^{-1}\right)$
(Cardoso et al., 2006), the $\mathrm{NO}_{3}$ absorption peak at $\left(1390 \mathrm{~cm}^{-1}\right)$ in the LDHs (Hussein et al., 2010), absorption peaks to $v(\mathrm{Mg}-\mathrm{O})$ at $\left(437 \mathrm{~cm}^{-1}\right)$ in layers and absorption peaks to $v(\mathrm{Fe}-\mathrm{O})$ at $\left(578 \mathrm{~cm}^{-1}\right)$ in layers (Cornejo et al., 2000) Table 5 and Fig. 7.

The nano compound $(\mathrm{Mg} / \mathrm{Fe}$-chloropyrifose- $\mathrm{LDH})$ appears many a new peaks this means successful for 
Table 5: Peaks of the $\left(\mathrm{Mg} / \mathrm{Fe}-\mathrm{NO}_{3}-\mathrm{LDH}\right)$ and the nano hybrid compound

\begin{tabular}{lcc}
\hline Frequencies & Hybrid compound & LDH \\
\hline O-Hv & 3483 & 3454 \\
$\mathrm{C}-\mathrm{H} v$ & 2362 & -- \\
Aliphatic & 1690 & --- \\
$\mathrm{C}=\mathrm{N}$ & & \\
Aromatic & 1516,1464 & -- \\
$\mathrm{C}=\mathrm{C}$ & & 1390 \\
Aromatic & 1381 & -- \\
$\mathrm{NO}_{3} \mathrm{v}$ & 1250 & -- \\
$\mathrm{P}-\mathrm{O}-$ Arylv & 1030 & --- \\
p-o-Alkylv & 690 & 437 \\
Ar-Civ & 434 & 578 \\
Mg-Ov & 586 & --- \\
v Fe-O & 669 & \\
$\delta$ C-H & & \\
Aromatic & & \\
\hline
\end{tabular}

Table 6: Value for $\left(\mathrm{r}^{2}, \mathrm{~K}_{0}, \mathrm{~K}_{1}, \mathrm{~K}_{2}\right)$ to equation zero, first and second order for release ion exchange from the nano compound layer prepare in ethanol by direct and in direct ion exchange in $(0.5 \mathrm{M})$ sodium carbonate and sodium phosphate

Nano compound prepare by direct ion exchang

\begin{tabular}{|c|c|c|c|c|c|c|}
\hline \multicolumn{2}{|c|}{ Second order } & \multicolumn{2}{|c|}{ First order } & \multicolumn{2}{|c|}{ Zero order } & \multirow[b]{2}{*}{ Samples } \\
\hline $\mathrm{R}^{2}$ & $\mathrm{~K}_{2} \mathrm{mg}^{-1} . \mathrm{L} / \mathrm{min}$ & $\mathrm{R}^{2}$ & $\mathrm{~K}_{1}(1 / \mathrm{min})$ & $\mathrm{R}^{2}$ & $\mathrm{mg} / \mathrm{min} . \mathrm{L}$ & \\
\hline$\overline{0.980}$ & 3.448 & 0.052 & 0.094 & -10.50 & 0.042 & $\mathrm{Na}_{2} \mathrm{CO}_{3}$ \\
\hline 0.932 & 1.562 & -12.600 & 0.041 & -0.61 & 0.032 & $\mathrm{Na}_{2} \mathrm{PO}_{4}$ \\
\hline 0.858 & 1.700 & 0.078 & 0.071 & -4.20 & 0.080 & $\mathrm{Na}_{2} \mathrm{CO}_{3}$ \\
\hline 0.826 & 1.302 & -10.700 & 0.043 & -8.20 & 0.300 & $\mathrm{Na}_{2} \mathrm{PO}_{4}$ \\
\hline
\end{tabular}

intercalation an ion (chloropyrophose) between the layars, absorption peaks of vO-H stretch in the $\left(3483 \mathrm{~cm}^{-1}\right)$. The peaks of aliphatic $v \mathrm{C}-\mathrm{H}$ stretch in the $\left(2362 \mathrm{~cm}^{-1}\right)$, peaks of $(\mathrm{vC}=\mathrm{C})$ aromatic apprarse at (1516 and $\left.1464 \mathrm{~cm}^{-1}\right)$, absorption peaks of $v C=N$ stretch ataromatic $1690 \mathrm{~cm}^{-1}$. The $\mathrm{NO}_{3}$ absorption peak at $1381 \mathrm{~cm}^{-1}$ in the LDHs absorption two peaks of $v(\mathrm{P}-\mathrm{O}-\mathrm{alkyl})$ and (P-O-aryl) at $\left(1030\right.$ and $\left.1250 \mathrm{~cm}^{-1}\right)$ but peak at the $\left(690 \mathrm{~cm}^{-1}\right)$ it is Cl-aryl, the peake $\delta_{\mathrm{C}-\mathrm{H}}$ aromatic apper at $\left(669 \mathrm{~cm}^{-1}\right)$, absorption peaks to $v(\mathrm{Mg}-\mathrm{O})$ at $\left(434 \mathrm{~cm}^{-1}\right)$ in layars and absorption peaks to $v\left(\mathrm{Fe}^{*} \mathrm{O}\right)$ at $\left(586 \mathrm{~cm}^{-1}\right)$ in layers (Cornejo et al., 2000) Table 5 and Fig. 8 .

The kinetic of ion exchange: To study the kinetic for controll release (Ho and Mckay, 2000) used Lagergran equation to zero order, first order and second order as the following:

$$
\begin{gathered}
\mathrm{C}_{\mathrm{t}}=\mathrm{K}_{0} \mathrm{t} \\
-\log \left(1-\frac{\mathrm{Ct}}{\mathrm{Cf}}\right)=\frac{\mathrm{K}_{1} \mathrm{t}}{2.303} \\
\frac{\mathrm{t}}{\mathrm{Ct}}=\frac{1}{\mathrm{~K}_{2} \mathrm{Cf}^{2}}+\frac{\mathrm{t}}{\mathrm{Cf}}
\end{gathered}
$$

Where:

$\mathrm{Ct}$ : Concentration at each time $\left(\mathrm{mg} \mathrm{L}^{-1}\right)$

$\mathrm{Ct}$ : Concentration at equilibrium $\left(\mathrm{mg} \mathrm{L}^{-1}\right)$

$\mathrm{K}_{0}$ : Constant rate ion exchange zero model $\left(\mathrm{mg} \mathrm{L}^{-1}\right.$ $\min ^{-1}$ )

$\mathrm{K}_{1}$ : Constant rate ion exchange first model $\left(\mathrm{min}^{-1}\right)$

$\mathrm{K}_{1}$ : Constant rate ion exchange second model $\left(\mathrm{mg}^{-1} \mathrm{~L}\right.$ $\min ^{-1}$ )

$\mathrm{t}:$ Reaction time (min)

Through the note of Table 6 and the kinetic figures for (chloropyrophose) release from the nano compound prepare by (direct ion exchange and in direct ion exchange) (Fig. 9a-f) in sodium carbonate medial and (Fig. 10a-f) for (chloropyrophose) release from the nano compound prepare by (direct ion exchange and in direct ion exchange) in sodium phosphate medial and the value $\left(\mathrm{r}^{2}\right)$ we note that the kinetic of ion exchange is model pseudo-second order.

When we note the value for the constant rate second $\left(\mathrm{K}_{2}\right)$ at (Fig. 9 and 10) result the rate kinetic release in different medial is as the following $\mathrm{Na}_{2} \mathrm{CO}_{3}>\mathrm{Na}_{2} \mathrm{PO}_{4}$.

The causes is that carbonate ion more electro file compare with sulfate ion and the figure of carbonate is triangular, so is easily intercalation with LDH than phosphate ion which is tetragonal. 

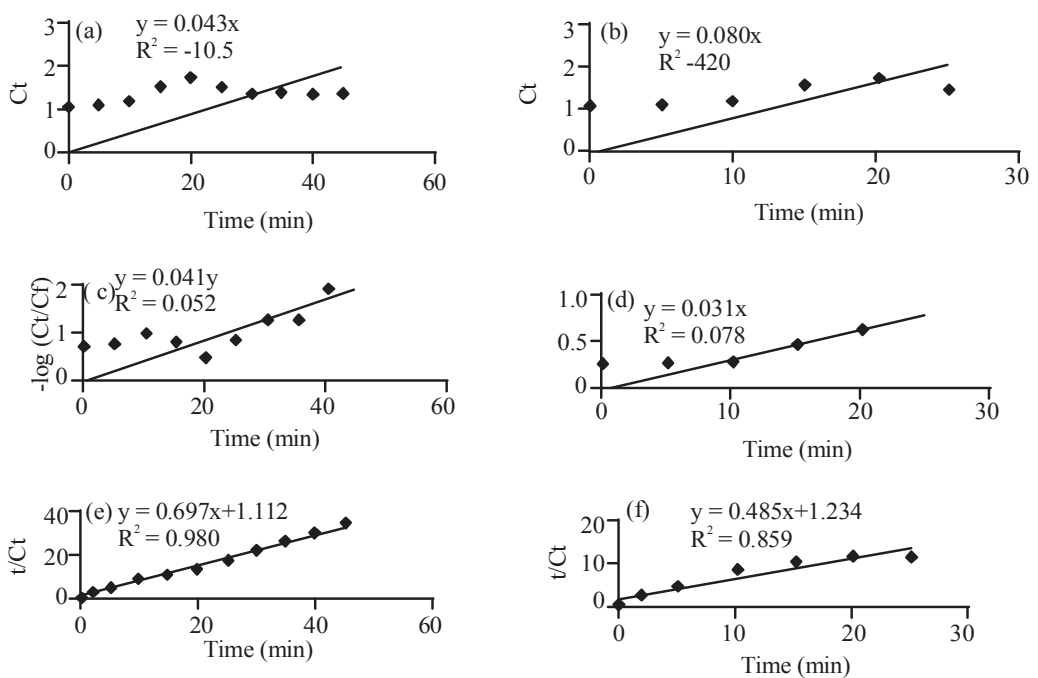

Fig. 9(a-f): Lagergan equation mdeil zero order ion exchange in sodium carbonate medial (a) Nano compound method by direct ion exchange (b) Nano compound method by indirect ion exchange; Lagergan equation mdeil first order ion exchange in sodium carbonate medial (c) Nano compound method by direct ion exchange (d) Nano compound method by indirect ion exchange; Lagergan equation mdeil second order ion exchange in sodium carbonate medial (e) Nano compound method by direct ion exchange (f) Nano compound method by indirect ion exchange
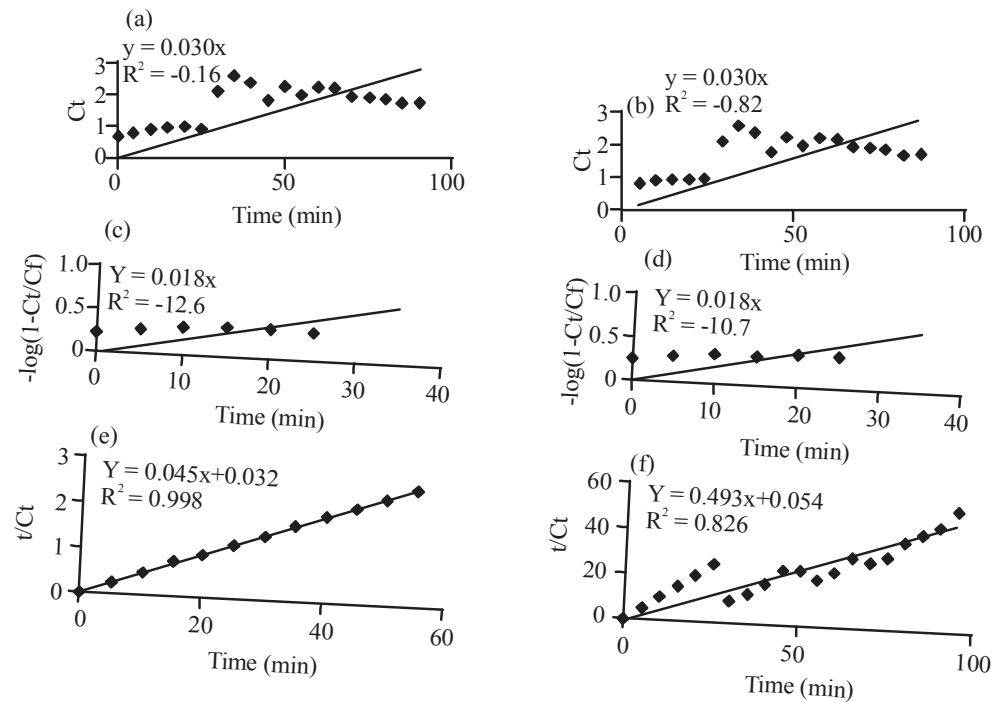

Fig. 10(a-f): Lagergan equation mdeil zero order ion exchange in sodium phosphate medial (a) Nano compound method by direct ion exchange (b) Nano compound method by indirect ion exchange; Lagergan equation mdeil first order ion exchange in sodium phosphate medial (c) Nano compound method by direct ion exchange (d) Nano compound method by indirect ion exchange; Lagergan equation mdeil second order ion exchange in sodium phosphate medial (e) Nano compound method by direct ion exchange and (f) Nano compound method by indirect ion exchange

Study percentage release for (chloropyrifose): The percentage release of (chloropyrifose) from the hybrid nano compound prepare in ethanol by direct and in direct ion exchange at $(0.5 \mathrm{M})$ from sodium carbonate and sodium phosphate medial used the linear equation as shown in Fig. 11a-d. Figure 11 and Table 7 from the results, we note the high value for percentage is the following $\mathrm{Na}_{2} \mathrm{CO}_{3}>\mathrm{Na}_{2} \quad \mathrm{PO}_{4}$. The percentage for in ion is high value in direct method than in direct method. 
Table 7: Value for (percentage for release anion (VC)) by ion exchange method from the nano compound layer prepare in ethanol by direct and in direct ion exchange in $(0.5 \mathrm{M})$ sodium carbonate and sodium phosphate

\begin{tabular}{lcccc}
\hline Nano compound prepare by direct ion exchange & & \\
$-\mathrm{K}$ & Time (min) & Chloropyrifose (\%) & Concentration Mol. L & \\
\hline 2.505 & 40 & 99 & $\mathrm{R}$ & $\mathrm{Na}_{2} \mathrm{CO}_{3}$ \\
0.761 & 110 & 85 & $\mathrm{Na}_{2} \mathrm{PO}_{4}$ & $\mathrm{Na}_{2} \mathrm{CO}_{3}$ \\
2.5 & 55 & 90 & $\mathrm{Na}_{2} \mathrm{PO}_{4}$ \\
0.411 & 140 & 77 & \\
\hline
\end{tabular}
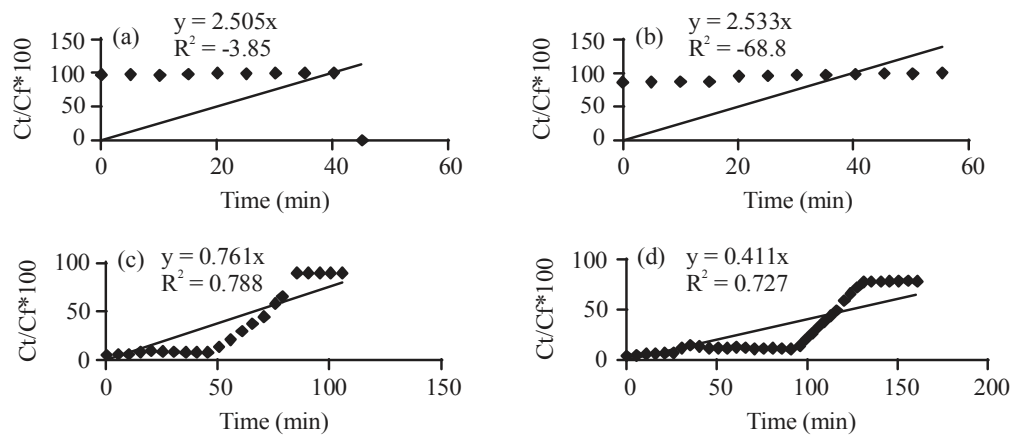

Fig. 11(a-d): Percentage of realaes (chloropyrifose) between the nano hyrbid compound in aquase medil from sodium carbonate $(0.5 \mathrm{M})$ (a) perpare nano compound by direct ion exchange method) (b) perpare nano compound by indirect ion exchange method); Percentage of realaes (chloropyrifose) between the nano hyrbid compound in aquase medil from sodium phosphate $(0.5 \mathrm{M})$ (c) Prepare nano compound by direct ion exchange method) and (d) Prepare nano compound by indirect ion exchange method)

\section{CONCLUSION}

The result appeared can be prepare nano compound hybrid by intercalation of insecticide (chlorpyrifos) as anion between $\mathrm{Mg} / \mathrm{Fe}$ double layer hydroxide by two method direct ion exchange and indirect ion exchange and study control release by direct ion exchange process to limited the problem of environment pollution and the healthily human. Where the kinetic control release is second order at $(0.5 \mathrm{M})$ from sodium carbonate and sodium phosphate. The high value kinetic release and percentage release at sodium carbonate. The study suggested ability use $\mathrm{Mg} / \mathrm{Fe}$ double layer hydroxide as gents chemical and agriculture material and control release inter the body of the insectto limited the pollution, this method is inexpensive in economic terms where this method is to give the insecticide in small quantities, so as not to harm health on the other does not leaked to the soil or ground water and thus causing pollution.

\section{REFERENCES}

Aisawa, S., S. Takahashi, W. Ogasawara, Y. Umetsu and E. Narita, 2001. Direct intercalation of amino acids into layered double hydroxides by coprecipitation. J. Solid State Chem., 162: 52-62.

Arizaga, G.G.C., J.E.F.D.C. Gardolinski, W.H. Schreiner and F. Wypych, 2009. Intercalation of an oxalatooxoniobate complex into layered double hydroxide and layered zinc hydroxide nitrate. J. Colloid Interface Sci., 330: 352-358.
Bragg, W.L., 1993. The diffraction of short electromagnetic waves by a crystal. Proc. Cambridge Philos. Soc., 17: 43-57.

Cardoso, L.P., R. Celis, J. Cornejo and J.B. Valim, 2006. Layered double hydroxides as supports for the slow release of acid herbicides. J. Agric. Food Chem., 54: 5968-5975.

Carlino, S., 1997. The intercalation of carboxylic acids into layered double hydroxides: A critical evaluation and review of the different methods. Solid State Ionics, 98: 73-84.

Cavani, F., F. Trifiro and A. Vaccari, 1991. Hydrotalcite-type anionic clays: Preparation, properties and applications. Catal. Today, 11: 173-301.

Cornejo, J., R. Celis, I. Pavlovic, M.A. Ulibarri and M.C. Hermosin, 2000. Structural changes in phenol-intercalulated hydrotalcite caused by heating. Clay Miner., 35: 771-779.

Evansa, D.G. and X. Duan, 2006. Preparation of layered double hydroxides and their applications as additives in polymers, as precursors to magnetic materials and in biology and medicine. Chem. Commun., 1: 485-496.

Franklin, K.R., E. Lee and C.C. Nunn, 1995. Preparation and characterisation of layered double hydroxides containing monovalent and divalent ions derived from 5-benzoyl- 4-hydroxy-2- methoxybenzenesul fonic acid. J. Mater. Chem., 5: 565-569. 
Ho, Y.S. and G. McKay, 2000. The kinetics of sorption of divalent metal ions onto sphagnum moss peat. Water Res., 34: 735-742.

Hussein, M.Z., F.A. Bahar and A.H. Yahya, 2010. Synthesis and characterization of hippurate-layered double hydroxide nanohybrid and investigation of its release property. J. Iran. Chem. Soc., 7: S42-S51.

Khan, A.I. and D. O'Hare, 2002. Intercalation chemistry of layered double hydroxides: Recent developments and applications. J. Mater. Chem., 12: 3191-3198.

Ookubo, A., K. Ooi and H. Hayashi, 1993. Preparation and phosphate ion-exchange properties of a hydrotalcite-like compound. Langmuir, 9: 1418-1422.

Raki, L., D.G. Rancourt and C. Detellier, 1995. Preparation, characterization and Moessbauer spectroscopy of organic anion intercalated pyroaurite-like layered double hydroxides. Chem. Mater., 7: 221-224.
Rives, V., 2001. Layered Double Hydroxides: Present and Future. Nova Science Publishers, Hauppauge, New York, USA., ISBN-13: 9781590330609, Pages: 439.

Shaheed, S.H., A.A.K. Al-Ghanimi and A.M. Bashi, 2014. Preparation of nanohybrid compound from the food preservative octyl gallate and studying some of its biological activities. Karbala J. Pharm. Sci., 5: 277-289.

Vaccari, A., 1998. Preparation and catalytic properties of cationic and anionic clays. Catal. Today, 41: 53-71.

Whilton, N.T., P.J. Vickers and S. Mann, 1997. Bioinorganic clays: Synthesis and characterization of amino-and polyamino acid intercalated layered double hydroxides. J. Mater. Chem., 7: 1623-1629. 